\title{
Antioxidant activity and phenolic contents of Olea europaea L. leaves sprayed with different copper formulations
}

\author{
Isabel C.F.R. Ferreira ${ }^{a}$, Lillian Barros ${ }^{a}$, Maria Elisa Soares ${ }^{b}$, Maria Lourdes Bastos ${ }^{b}$, \\ José Alberto Pereira ${ }^{a, *}$ \\ ${ }^{a}$ CIMOlEscola Superior Agrária de Bragança, Quinta de Sta Apolónia, Apartado 1172, 5301-855 Bragança, Portugal \\ ${ }^{\mathrm{b}}$ REQUIMTE/ Serviço de Toxicologia, Faculdade de Farmácia Universidade do Porto, R. Aníbal Cunha, 164, 4050-047 Porto, Portugal
}

Received 3 March 2006; received in revised form 11 April 2006; accepted 2 August 2006

\begin{abstract}
Olive trees (Olea europaea L. Cv. Cobrançosa) from the northeast of Portugal were sprayed with three different copper formulations [bordeaux mixture (copper sulphate + calcium hydroxide $-20 \% \mathrm{Cu})$, copper hydroxide $(40 \% \mathrm{Cu})$ and copper oxychloride $(50 \% \mathrm{Cu})$ ] to control olive fungal diseases. The residues of copper in olive leaves, harvested at different times, were evaluated by atomic absorption spectrometry. At all the collection times, treated olive leaves had significantly higher copper contents, compared to the control. The different copper amounts in pesticide formulations lowered the leaves contents in total phenols and hence their antioxidant properties. Olive leaves sprayed with copper oxychloride possessed the highest copper levels and the lowest content in phenols, which influenced its antioxidant activity (higher $\mathrm{EC}_{50}$ values for reducing power, scavenging effect on DPPH radicals and inhibition of erythrocyte hemolysis). Leaves without copper residues proved to be a good natural source of antioxidants, giving values comparable to the reference compounds.
\end{abstract}

(C) 2006 Elsevier Ltd. All rights reserved.

Keywords: Olea europaea; Olive leaves; Copper; Phenols; Antioxidant activity

\section{Introduction}

Olive tree (Olea europaea L.) is one of the most important fruit trees in Mediterranean countries, where they cover $\sim 8$ million ha, accounting for almost $98 \%$ of the world crop. This demonstrates the great economic and social importance of this crop and the possible benefits to be derived from utilisation of any of its by products (Guinda, Albi, Camino, \& Lanzón, 2004; Tabera et al., 2004). Olive leaves are one of the by products of farming of the olive grove; they can be found in high amounts in the olive oil industries $(10 \%$ of the total weight of the olives) and they accumulate during pruning of the olive trees (Tabera et al., 2004). Popular medicine and phyto-

\footnotetext{
* Corresponding author. Tel.: +351 273303277; fax: +351 273325405.

E-mail address: jpereira@ipb.pt (J.A. Pereira).
}

therapy use olive leaves to treat and prevent hypertension, and for their hypoglycaemic, antiseptic and diuretic properties (Bruneton \& Iridoides, 1993; Hellemont, 1986; PDR, 1998). They were formerly used as a folk remedy for combatting fevers and other diseases, such as malaria, but this use was dropped (PDR, 1998). Several reports have shown that olive leaf extract has the capacity to lower blood pressure in animals (Samuelsson, 1951) and increase blood flow in the coronary arteries (Zarzuelo, 1991), relieve arrhythmia and prevent intestinal muscle spasms (Garcia, Castillo, Lorente, Ortuno, \& Del-Rio, 2000).

There is an increasing interest in the phenolic compounds in olive by-products, due to their biological properties. Olive oil polyphenols possess good antioxidant activities (Gordon, Paiva-Martins, \& Almeida, 2001; Paiva-Martins, Gordon, \& Gameiro, 2003). Also olive leaves are a source of several antioxidants (Benavente-García, Castillo, Lorente, Ortuño, \& Del Rio, 2000; Bouaziz \& Sayadi, 2005; Briante, 
Cara, Febbraio, Patumi, \& Nucci, 2002; Briante et al., 2002; Meirinhos et al., 2005; Paiva-Martins \& Gordon, 2001; Ranalli et al., 2006; Savournin et al., 2001).

Olive tree is attacked by more than fifty diseases that cause a reduction in quantity and quality of olive fruits and therefore in olive oil production. To control these diseases, sprays are applied twice a year, once at the end of winter/beginning of spring and once at the beginning of autumn (Trapero \& Blanco, 1999). Copper oxychloride, copper sulphate, copper hydroxide, cuprous oxide and Ziram are registered and are currently used in Portuguese olive groves to prevent the diseases referred above (Gomes \& Cavaco, 2003). Nevertheless, the presence of this metal could catalyse oxidation of fatty acid chains, exerting a deleterious influence over shelf life. Transition metals, which possess two or more valence states with a suitable redox potential, act as pro-oxidants even at concentrations lower than $0.1 \mathrm{ppm}$, and could affect the speed of autoxidation.

Copper is a transition metal that even, in small concentrations, is a very potent oxidation catalyst (De Leonardis \& Macciola, 2002; La Pera, Lo Coco, Mavrogeni, Giuffrida, \& Dugo, 2002) and can participate in redox reactions, giving rise to consequent lipid peroxidation phenomenon, due to the free radicals produced (Aust \& Sringen, 1982; Pryor, Lightsey, \& Prier, 1982; Torel, Cillard, \& Cillard, 1986). This group of reactive species (superoxide, hydroxyl and lipidic peroxides) may interact with biological systems in a clearly cytotoxic manner, being responsible for several pathological processes, such as certain tumours (prostate and colon cancers) (Keys, 1995) and coronary heart disease (Lipworth, Martinez, Angell, Hsien, \& Trichopoulos, 1997). In this respect, olive flavonoids, phenols and oleuropeosides have been shown to possess important antioxidant activity towards these radicals, which is principally based on the redox properties of their phenolic hydroxyl groups and the structural relationships between different parts of their chemical structure (Bors \& Saran, 1987; Visioli, Bellomo, \& Galli, 1998; Visioli, Bellosta, \& Galli, 1998).

In the past few years, the suspected toxicity of some synthetic compounds used in food has raised interest in natural products (Fukushima \& Tsuda, 1985; Stone, Leclair, Ponder, Bagss, \& Barret-Reis, 2003). Some industries, such as those related to food additive production, cosmetics, and pharmaceuticals, have increased their efforts in obtaining bioactive compounds from natural products by extraction and purification. Antioxidant compounds can increase shelf life by retarding the process of lipid peroxidation, which is one of the major reasons for deterioration of food products during processing and storage (Halliwell, 1997; Halliwell \& Gutteridge, 1999). Thus a need for identifying alternative natural and safe sources of food antioxidants has been created, and the search for natural antioxidants, especially of plant origin, has notably increased in recent years (Skerget et al., 2005).

In the present study we have evaluated the residual levels of copper in olive leaves, as a result of tree pulverisations with copper formulations and to correlate these levels with antioxidant activity of the respective leave extracts. As far as we know, it is the first time that a study on the influence of copper residues from different pesticide formulations on the antioxidant activity of olive leaves is reported. Copper contents were evaluated by electrothermic atomisation atomic absorption spectrometry in $C v$. Cobrançosa olive leaves from Northeast Portugal pulverised with different copper formulations to control fungal diseases. In order to compare the presence of copper residues in the leaves with their antioxidant properties, several chemical assays were performed. The reducing power, the scavenging effects on DPPH (1,1-diphenyl-2-picrylhydrazyl) radicals and the protective effect of the leaves' methanolic extracts on erythrocyte hemolysis by peroxyl radical scavenging activity were investigated and compared with the total phenolic amount.

\section{Materials and methods}

\subsection{Field trials}

The field trials were carried out in an olive grove located in Trás-os-Montes, Northeast Portugal. The trees belong to the $C v$. Cobrançosa, one of the most important cultivars in the region, representing about $85 \%$ of the cultivated trees in young orchards (Monteiro, 1999). Production and phytosanitary protection were done according to the Integrated Production Management guidelines (Soveral-Dias et al., 2000) and the Integrated Protection Management guidelines (Gomes \& Cavaco, 2003), respectively. The orchard was subdivided in four plots, three of them for application of different copper preparations and one for control. Treatments were carried out on October 15th, 2003, with a motorised sprayer (Tomix P12, APS121; Tomix-Indústria de Equipamentos Agrícolas e Indústriais, Lda. Torres Vedras, Portugal). The commercial formulations were Bordeaux mixture Valles $\left[\mathrm{CuSO}_{4}+\mathrm{Ca}(\mathrm{OH})_{2}\right.$ with $20 \% \mathrm{Cu}$; Valles, Portugal], Kocide DF $\left[\mathrm{Cu}(\mathrm{OH})_{2}\right.$ with $40 \% \mathrm{Cu}$; Agroquisa, Lisbon, Portugal] and Curenox 50 $\left[\mathrm{Cu}(\mathrm{OCl})_{2}\right.$ with $50 \% \mathrm{Cu}$; Valles, Portugal] and were used in the recommended doses. The control plot was sprayed with water. The weather conditions (Fig. 1) were continuously recorded with an automatic weather station. Sample collection was performed $4 \mathrm{~h}$, and $8,13,28$ and 44 days

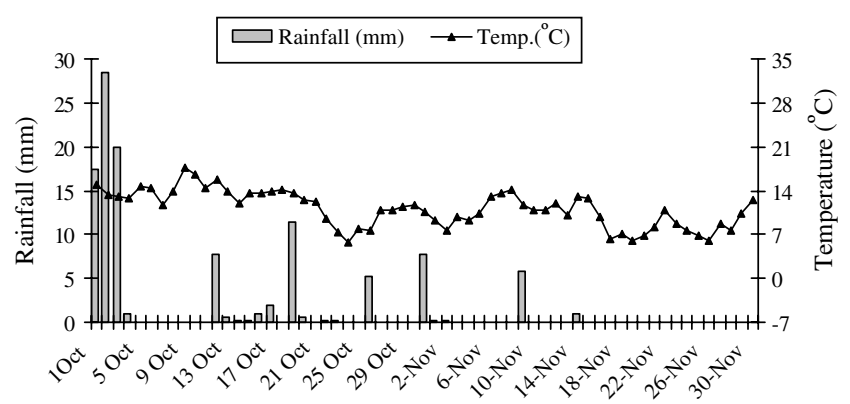

Fig. 1. Climatic conditions during the experiment. 
after treatment. In each sampling and treatment, five trees $(n=5)$ were randomly selected in the middle of each plot, and 60 healthy olive leaves per tree were collected at the operator height around the whole perimeter of each tree. The samples were stored in plastic bags at $-20{ }^{\circ} \mathrm{C}$ until further analysis.

\subsection{Reagents and materials}

Reference compounds BHA (2-tert-butyl-4-methoxyphenol), $\alpha$-tocopherol and gallic acid were purchased from Sigma Chemical Co. (St. Louis, MO, USA). 2,2Diphenyl-1-picrylhydrazyl (DPPH) was obtained from Alfa Aesar (Karlsruhe, Germany). All other chemicals used in the antioxidant activity assays were obtained from Sigma Chemical Co. Methanol was obtained from Pronalab (Lisboa, Portugal). Water was treated in a Milli-Q water purification system (Millipore Ibérica S.A., Madrid, Spain).

For copper determination all the solutions were prepared with doubly de-ionized water and the chemicals used were of Suprapur grade (Merck Darmstadt, Germany). Copper standard was prepared daily from $1000 \mathrm{mg} / \mathrm{l}$ solutions (Tritisol, Merck) in $\mathrm{HNO}_{3}(0.2 \%)$.

\subsection{Copper determination}

Sample preparation: Copper determinations $(n=5)$ were performed for samples collected at all times $(4 \mathrm{~h}$, and 8,13 , 28 and 44 days after treatment), and for each treatment (Bordeaux mixture, copper hydroxide, copper oxychloride and water). In each sample the olive leaves were cut into small portions with a plastic knife previously rinsed with $\mathrm{HNO}_{3}(15 \%)$ and ultrapure water, packed in PVC decontaminated tubes and dried at $60{ }^{\circ} \mathrm{C}$ for several days. The dried samples were reduced to powder in a Teflon container, and about $0.25 \mathrm{~g}$ were weight and transferred to another teflon container, which, after addition of $2 \mathrm{ml}$ of $\mathrm{HNO}_{3}$ and $250 \mu \mathrm{l}$ of $\mathrm{H}_{2} \mathrm{O}_{2}$, was closed for digestion overnight in an oven thermostatically controlled at $85 / 90{ }^{\circ} \mathrm{C}$. The digested solution was transferred to a decontaminated tube and diluted to a convenient volume with doubly deionised water.

Apparatus: Metal quantifications were carried out in a Perkin-Elmer HGA-850 furnace installed in a Model $A$ Analyst 300 spectrometer with deuterium arc background correction, equipped with an AS-800 Autosampler. The analyses were performed using Perkin-Elmer HGA tubes with integrated platform. The furnace programme temperatures were $1100{ }^{\circ} \mathrm{C}$ and $2300{ }^{\circ} \mathrm{C}$ for ashing and atomisation steps, respectively.

\subsection{Phenolic content determination}

The leaves used in the antioxidant activity experiments were collected 44 days after treatment with each copper formulation. The leaves sprayed with the same formulation were mixed together, powdered and divided into three samples $(n=3)$. A fine dried leaves powder (20 mesh) sample $(5 \mathrm{~g})$ was extracted with methanol in a Soxhlet apparatus for $7 \mathrm{~h}$. The methanolic extract was evaporated at $40{ }^{\circ} \mathrm{C}$ to dryness and redissolved in methanol at a concentration of $50 \mathrm{mg} / \mathrm{ml}$, and stored at $4{ }^{\circ} \mathrm{C}$ for further use. Phenolic compounds' concentration in the leaves' methanolic extracts was estimated by a colorimetric assay, based on procedures described by Singleton and Rossi with some modifications (Singleton \& Rossi, 1965). Briefly, $1 \mathrm{ml}$ of sample was mixed with $1 \mathrm{ml}$ of Folin and Ciocalteu's phenol reagent. After $3 \mathrm{~min}, 1 \mathrm{ml}$ of saturated $\mathrm{Na}_{2} \mathrm{CO}_{3}$ solution was added to the mixture and adjusted to $10 \mathrm{ml}$ with distilled water. The reaction was kept in the dark for $90 \mathrm{~min}$, after which the absorbance was read at $725 \mathrm{~nm}$ (AnalytikJena 200-2004 spectrophotometer Jena, Germany). Gallic acid was used to calculate the standard curve $(0.01-0.4 \mathrm{mM})$. The results are expressed as milligram of gallic acid equivalents/g of extract (GAEs).

\subsection{Reducing power assay}

The reducing power was determined according to the method of Oyaizu (Oyaizu, 1986). Various concentrations of leaves' methanolic extracts $(2.5 \mathrm{ml})$ were mixed with $2.5 \mathrm{ml}$ of $200 \mathrm{mmol} / 1$ sodium phosphate buffer $(\mathrm{pH}$ 6.6) and $2.5 \mathrm{ml}$ of $1 \%$ potassium ferricyanide. The mixture was incubated at $50{ }^{\circ} \mathrm{C}$ for $20 \mathrm{~min}$. After $2.5 \mathrm{ml}$ of $10 \%$ trichloroacetic acid $(\mathrm{w} / \mathrm{v})$ were added, the mixture was centrifuged at $1000 \mathrm{rpm}$ for $8 \mathrm{~min}$ (Centurion K24OR refrigerated centrifuge Centurion Scientific, Arundel, UK). The upper layer $(5 \mathrm{ml})$ was mixed with $5 \mathrm{ml}$ of deionised water and $1 \mathrm{ml}$ of $0.1 \%$ of ferric chloride, and the absorbance was measured spectrophotometrically at $700 \mathrm{~nm}$ : higher absorbance indicates higher reducing power. The extract concentration providing 0.5 of absorbance $\left(\mathrm{EC}_{50}\right)$ was calculated from the graph of absorbance at $700 \mathrm{~nm}$ against extract concentration. BHA and $\alpha$-tocopherol were used as reference compounds.

\subsection{Radical-scavenging activity (RSA) assay}

The capacity to scavenge the "stable" free radical 2,2diphenyl-1-picrylhydrazyl (DPPH) was monitored according to the method of (Hatano, Kagawa, Yasuhara, \& Okuda, 1988). Various concentrations of methanolic extracts from leaves $(0.3 \mathrm{ml})$ were mixed with $2.7 \mathrm{ml}$ of methanolic solution containing DPPH radicals $\left(6 \times 10^{-5}\right.$ $\mathrm{mol} / \mathrm{l})$. The mixture was shaken vigorously and left to stand for $60 \mathrm{~min}$ in the dark (until stable absorption values were obtained). The reduction of the DPPH-radical was measured by monitoring continuously the decrease of absorption at $517 \mathrm{~nm}$. The radical scavenging activity (RSA) was calculated as a percentage of DPPH discolouration using the equation:

$\% \mathrm{RSA}=\left[\left(A_{\mathrm{DPPH}}-A_{\mathrm{S}}\right) / A_{\mathrm{DPPH}}\right] \times 100$, 
where $A_{\mathrm{S}}$ is the absorbance of the solution when the sample extract has been added at a particular level, and $A_{\mathrm{DPPH}}$ is the absorbance of the DPPH solution. The extract concentration providing $50 \%$ inhibition $\left(\mathrm{EC}_{50}\right)$ was calculated from the graph of RSA percentage against extract concentration. BHA and $\alpha$-tocopherol were used as reference compounds.

\subsection{Assay for erythrocyte hemolysis mediated by peroxyl free radicals}

The antioxidant activity of the leaves' methanolic extracts was measured as the inhibition of erythrocyte hemolysis (Miki, Tamia, Mino, Yamamoto, \& Niki, 1987). Blood was obtained from a male ram of body weight $\sim 67 \mathrm{~kg}$. Erythrocytes separated from the plasma and the buffy coat were washed three times with $10 \mathrm{ml}$ of $10 \mathrm{mmol}$ phosphate buffer saline (PBS) at $\mathrm{pH} 7.4$ (prepared by mixing $10 \mathrm{mmol}$ of $\mathrm{NaH}_{2} \mathrm{PO}_{4}$ and $10 \mathrm{mmol} \mathrm{Na}_{2} \mathrm{HPO}_{4}$, and $125 \mathrm{mmol}$ of $\mathrm{NaCl}$ in 11 of distilled water) and centrifuged at $1500 \mathrm{~g}$ for 5 min. During the last washing, the erythrocytes were obtained by centrifugation at $1500 \mathrm{~g}$ for $10 \mathrm{~min}$. A $0.1 \mathrm{ml}$ of a $20 \%$ suspension of erythrocytes in PBS was added to

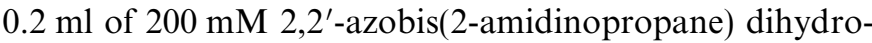
chloride (AAPH) solution (in PBS) and $0.1 \mathrm{ml}$ of leaves' methanolic extracts of different concentrations. The reaction mixture was shaken gently while being incubated at $37^{\circ} \mathrm{C}$ for $3 \mathrm{~h}$. The reaction mixture was diluted with $8 \mathrm{ml}$ of PBS and centrifuged at $3000 \mathrm{~g}$ for $10 \mathrm{~min}$; the absorbance of its supernatant was then read at $540 \mathrm{~nm}$ (absorbance A), after filtration with a syringe filter (cellulose membrane $30 \mathrm{~mm}$, $0.20 \mu \mathrm{m})$. The percentage of hemolysis inhibition was calculated by the equation:

\%hemolysis inhibition $=\left[\left(A_{\mathrm{AAPH}}-A_{\mathrm{S}}\right) / A_{\mathrm{AAPH}}\right] \times 100$,

where $A_{\mathrm{S}}$ is the absorbance of the sample containing the leaves extract, and $A_{\mathrm{AAPH}}$ is the absorbance of the control sample containing no leaves' extract. The extract concentration providing $50 \%$ inhibition $\left(\mathrm{EC}_{50}\right)$ was calculated from the graph of hemolysis inhibition percentage against extract concentration. L-Ascorbic acid was used as standard.

\subsection{Statistical analysis}

The copper determinations were carried out in duplicate. The results for the five samples are expressed as mean values and standard error, for all sampling periods and treatments. The differences in copper concentration across the different treatments were analysed using analysis of variance followed by a Tukey Test with $\alpha=0.05$. This treatment was carried out using SAS v. 9.1.3 program. For the antioxidant activity the assays were carried out in triplicate and the results are expressed as mean values \pm standard errors.

\section{Results and discussion}

\subsection{Copper residues on olive leaves}

Calibration against acidified standard solutions was performed and the linear range established for copper was from 0.19 to $20.0 \mu \mathrm{g} / \mathrm{l}$. The limit of detection was calculated as the concentration corresponding to three times the standard deviation (SD) of the background noise and the value found was $0.19 \mu \mathrm{g} / 1$. The limit of quantification was $15.2 \mathrm{pg}$.

The precision of the analytical method and the overall procedure was less than $10 \%$, under the analytical conditions established. The accuracy of the procedure was evaluated by analysing a Certified Reference Material (Spinach Leaves, 1570a) supplied by National Institute of Standards \& Technology (NIST). The certified value was $12.2 \pm$ $0.6 \mu \mathrm{g} / \mathrm{g}$ and the value found by applying the implemented methodology was $11.9 \pm 0.4 \mu \mathrm{g} / \mathrm{g}$.

The copper levels in the olive leaves collected at $4 \mathrm{~h}$ and $8,13,28$ and 44 days after tree treatment with three copper formulations are presented in Fig. 2; results are expressed in terms of mean values and in $\mu \mathrm{g} / \mathrm{g}$ dry weight. At all collection times, the treated leaves showed significantly higher copper concentration than the leaves collected from the control (pulverized with water). The levels found in the leaves collected $4 \mathrm{~h}$ after treatment were about 20 times higher for $\mathrm{CuSO}_{4}+\mathrm{Ca}(\mathrm{OH})_{2}(20 \% \mathrm{Cu}), 17$ times higher for $\mathrm{Cu}(\mathrm{OH})_{2}(40 \% \mathrm{Cu})$ and 28 times higher for $\mathrm{Cu}(\mathrm{OCl})_{2}$ $(50 \% \mathrm{Cu})$ than the control. The results obtained were $512.5,440.0,725.0$ and $26.0 \mu \mathrm{g} / \mathrm{g}$ dry weight for $\mathrm{CuSO}_{4}+$ $\mathrm{Ca}(\mathrm{OH})_{2}, \mathrm{Cu}(\mathrm{OH})_{2}, \mathrm{Cu}(\mathrm{OCl})_{2}$ and water, respectively. The copper concentration in treated leaves progressively decreased with the time (Fig. 2). For the three copper formulations there was good correlation between collection time and copper concentration in the olive leaves (linear regression coefficients 0.930 for copper hydroxide, 0.973 for copper oxychloride and 0.987 for bordeaux mixture). Regarding the half-life times for copper disappearance in

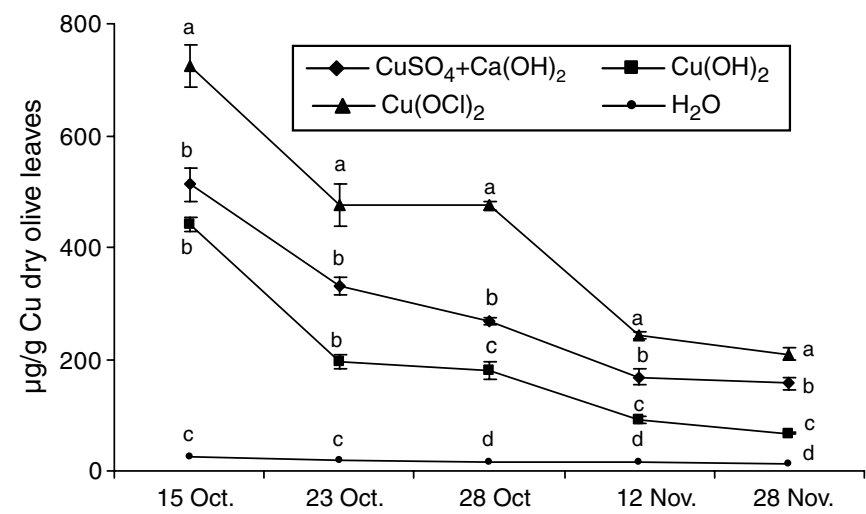

Fig. 2. Content of $\mathrm{Cu}$ (mean $\pm \mathrm{SE}$ ) in olive leaves (mg/g dry olives) after $4 \mathrm{~h}, 8,13,28$ and 44 days of each treatment. Different letters means significant differences $(p<0.05)$ between treatments in each date $(n=5)$. 
leaves, we observed that $\mathrm{Cu}(\mathrm{OCl})_{2}$ is the most persistent (Table 1). Even in the leaves collected 44 days after treatment, copper levels remained significantly higher in the treated samples $(p<0.05) \quad\left(156.0 \mu \mathrm{g} / \mathrm{g}\right.$ for $\mathrm{CuSO}_{4}+$ $\mathrm{Ca}(\mathrm{OH})_{2}, \quad 67.0 \mu \mathrm{g} / \mathrm{g}$ for $\mathrm{Cu}(\mathrm{OH})_{2}$, and $208.3 \mu \mathrm{g} / \mathrm{g}$ for $\left.\mathrm{Cu}(\mathrm{OCl})_{2}\right)$ than the control $(12.0 \mu \mathrm{g} / \mathrm{g})$.

The presence of copper in olive leaves is due to both endogenous factors, related to the plant metabolism, and exogenous factors due to agronomic practices, such as fertilisation and phytosanitary treatments. In our study, the leaves were from the same cultivar and the same orchard, and the climatic conditions during the experiment were similar (Fig. 1). In this sense, the high copper levels present in the olive leaves are due to the phytosanitary treatment.

\subsection{Antioxidant activity and phenols content}

It had been reported that the antioxidant activity of plant materials is well correlated with the content of their phenolic compounds (Skerget et al., 2005). Table 2 shows the phenols concentration in the leaves' extracts, expressed as milligram of gallic acid equivalents (GAEs) per gram of extract.

The copper preparations used to control olive fungal diseases had an influence on the results obtained. As expected, the leaves extracts without any treatment showed higher phenolic content $(12.7 \pm 0.040 \mathrm{mg} / \mathrm{g})$ than extracts obtained from leaves treated with different copper preparations. Copper remaining in the leaves can elicit the formation of reactive oxygen species, which are neutralised by the polyphenolic compounds, resulting in the lowering of their antioxidant capacities. The leaves sprayed with copper oxychloride $(50 \% \mathrm{Cu})$ contained the lowest concentration of phenolic compounds $(5.3 \pm 0.056 \mathrm{mg} / \mathrm{g})$. The amount found in leaves treated with copper hydroxide $(40 \% \mathrm{Cu})$ was slightly lower compared to the treatment with Bordeaux mixture $(20 \% \mathrm{Cu})(8.5 \pm 0.021 \mathrm{mg} / \mathrm{g}$ and $9.1 \pm$ $0.019 \mathrm{mg} / \mathrm{g}$, respectively).

Table 1

Relationship between time of Olea europaea L. ( $C v$. Cobrançosa) leaves collection and copper concentration

\begin{tabular}{llll}
\hline Pesticide & Equation & $r^{2}$ & $\begin{array}{l}t_{1 / 2} \\
\text { (days) }\end{array}$ \\
\hline $\mathrm{Cu}(\mathrm{OH})_{2}$ & $y=0.3243 x^{2}-21.677 x+406.04$ & 0.930 & 10.4 \\
$\mathrm{Cu}(\mathrm{OCl})_{2}$ & $y=0.322 x^{2}-25.575 x+710.37$ & 0.973 & 27.5 \\
$\mathrm{CuSO}_{4}+\mathrm{Cu}(\mathrm{OH})_{2}$ & $y=0.3049 x^{2}-21.032 x+497.9$ & 0.987 & 14.6 \\
\hline
\end{tabular}

$r^{2}-$ coefficient of determination; $t_{1 / 2}-$ half-life times of copper disappearance in leaves.

\subsection{Reducing power assay}

Fig. 3 shows the reducing power of leaves' methanolic extracts, as a function of their concentration. In this assay, the yellow colour of the test solution changes to various shades of green and blue, depending on the reducing power of each compound. The presence of reducers (i.e., antioxidants) causes the reduction of the $\mathrm{Fe}^{3+} /$ ferricyanide complex to the ferrous form. Therefore, measuring the formation of Perl's Prussian blue at $700 \mathrm{~nm}$ can monitor the $\mathrm{Fe}^{2+}$ concentration.

The reducing power of the leaves' methanolic extracts increased with concentration. Reducing powers for the different leaves were higher than 0.8 at $5 \mathrm{mg} / \mathrm{ml}$, and in the order of $\mathrm{H}_{2} \mathrm{O}>\mathrm{Cu}(\mathrm{OH})_{2} \approx \mathrm{CuSO}_{4}+\mathrm{Ca}(\mathrm{OH})_{2}>\mathrm{Cu}(\mathrm{OCl})_{2}$. Reducing power of BHA at $3.6 \mathrm{mg} / \mathrm{ml}$ and $\alpha$-tocopherol at $8.6 \mathrm{mg} / \mathrm{ml}$ were only 0.12 and 0.13 , respectively. Methanolic extracts from leaves sprayed with $\mathrm{Cu}(\mathrm{OCl})_{2}$ showed the lowest reducing power. It must be emphasized that the leaves collected from trees treated with this formulations presented the highest levels of copper residues. The extracts obtained from the leaves without any treatment proved to be a better source of antioxidants than extracts from the other leaves.

\subsection{Radical-scavenging activity (RSA) assay}

The RSA of leaves' extracts was evaluated using a methanolic solution of the "stable" free radical, DPPH. A freshly prepared DPPH solution exhibits a deep purple colour with an absorption maximum at $517 \mathrm{~nm}$. This purple

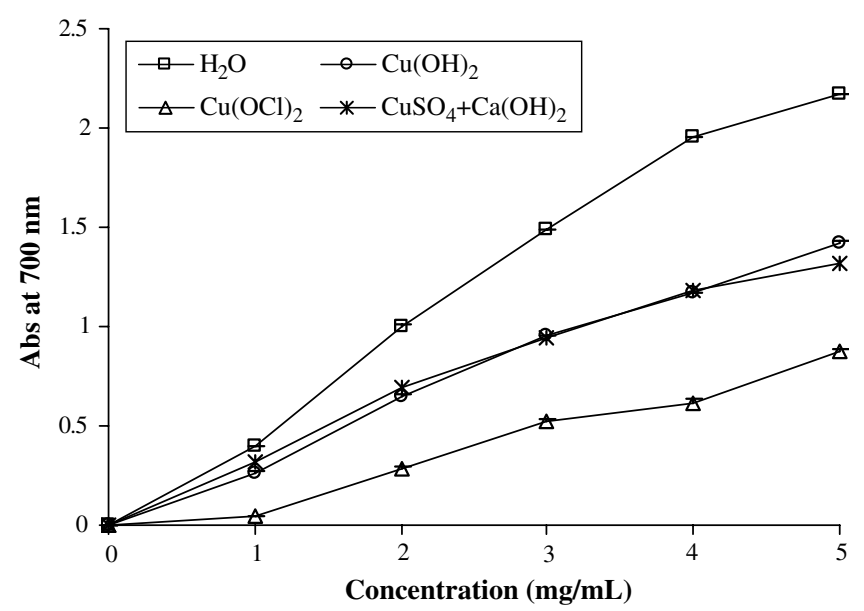

Fig. 3. Reducing power, of methanolic extracts from Olea europaea L. ( $C v$. Cobrançosa) leaves. Each value is expressed as mean \pm standard deviation $(n=3)$.

Table 2

Total phenols contents in methanolic leaves extracts $(\mathrm{mg} / \mathrm{g})$

\begin{tabular}{lllll}
\hline & $\mathrm{H}_{2} \mathrm{O}$ & $\mathrm{Cu}(\mathrm{OH})_{2}$ & $\mathrm{Cu}(\mathrm{OCl})_{2}$ & $\mathrm{CuSO}{ }_{4}+\mathrm{Cu}(\mathrm{OH})_{2}$ \\
\hline Total phenols content $^{\mathrm{a}}(\mathrm{mg} / \mathrm{g})$ & $12.7 \pm 0.040$ & $8.5 \pm 0.021$ & $5.3 \pm 0.056$ & $9.1 \pm 0.019$ \\
\hline
\end{tabular}

\footnotetext{
${ }^{\text {a }}$ Each value is expressed as mean \pm standard deviation $(n=3)$.
} 
colour generally fades/disappears when an antioxidant is present in the medium. Thus, antioxidant molecules can quench DPPH free radicals (i.e., by providing hydrogen atoms or by electron donation, conceivably via a free-radical attack on the DPPH molecule) and convert them to a colourless/bleached product (i.e., 2,2-diphenyl-1-hydrazine, or a substituted analogous hydrazine), resulting in a decrease in absorbance at $517 \mathrm{~nm}$. Hence, the more rapidly the absorbance decreases, the more potent the antioxidant activity of the extract. Free radical scavenging is one of the known mechanisms by which antioxidants inhibit lipid oxidation. This test is a commonly employed assay in antioxidant studies of specific compounds or extracts over a short time scale (Ferreira et al., 2006; Ferreres et al., 2006).

The RSA values of methanolic extracts from leaves sprayed with different copper compounds were examined (Fig. 4); results are expressed as the ratio percentage of sample absorbance decrease and the absorbance of DPPH solution in the absence of extract at $517 \mathrm{~nm}$.

From the analysis of Fig. 3 we can conclude that the scavenging effects of leaves' methanolic extracts on DPPH radicals increased with the concentration increase and were high $(87.1-100 \%$ at $5 \mathrm{mg} / \mathrm{ml})$, and comparable to the RSA values obtained for the standards BHA $(96 \%$ at $3.6 \mathrm{mg} / \mathrm{ml})$ and $\alpha$-tocopherol $(95 \%$ at $8.6 \mathrm{mg} / \mathrm{ml})$. The extracts obtained from the leaves without any copper treatment scavenged DPPH radicals more effectively $(100 \%$ at $5 \mathrm{mg} /$ $\mathrm{ml}$ ) than extracts from the other leaves. The use of $\mathrm{Cu}(\mathrm{OCl})_{2} \mathrm{decreased}$ the $\mathrm{RSA}$ values $(87.1 \%$ at $5 \mathrm{mg} / \mathrm{ml})$.

\subsection{Assay for erythrocyte hemolysis}

AAPH is a peroxyl radical initiator that generates free radicals by its thermal decomposition and will attack erythrocytes, to induce the chain oxidation of lipid and protein, disturbing the membrane organisation and eventually leading to hemolysis. In this study, the protective effect of the compound solution on erythrocyte hemolysis by peroxyl

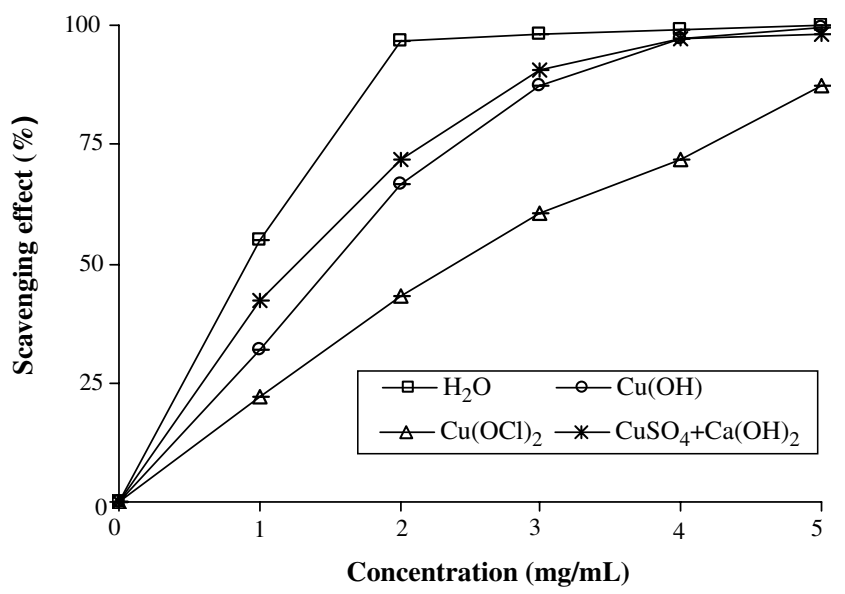

Fig. 4. Scavenging activity (\%) on DPPH radicals of methanolic extracts from Olea europaea L. ( $\mathrm{Cv}$. Cobrançosa) leaves. Each value is expressed as mean \pm standard deviation $(n=3)$. radical scavenging activity was investigated. Fig. 5 shows the percentage inhibition of hemolysis induced by AAPH in ram erythrocytes.

The methanolic extracts inhibited hemolysis of erythrocytes in a concentration-dependent manner. Once more, leaves without any treatment showed a higher percentage inhibition of hemolysis $(100 \%$ at $50 \mathrm{mg} / \mathrm{ml})$ than the other leaves $\left(72.1 \%\right.$ for $\mathrm{CuSO}_{4}+\mathrm{Ca}(\mathrm{OH})_{2}, 60.6 \%$ for $\mathrm{Cu}(\mathrm{OH})_{2}$ and $19 \%$ for $\mathrm{Cu}(\mathrm{OCl})_{2}$ ) which indicated that copper decreases the protective effect against hemolysis of erythrocytes. Leaves sprayed with $\mathrm{CuSO}_{4}+\mathrm{Ca}(\mathrm{OH})_{2}$ and $\mathrm{Cu}(\mathrm{OH})_{2}$ exhibited a similar inhibition effect. The inhibition percentage of the standard L-ascorbic acid on hemolysis of red blood cell was higher $(94.6 \%$ at $1 \mathrm{mg} / \mathrm{ml})$ than those of leaves' extracts.

A relationship between the inhibition percentage of hemolysis and reducing power of RSA was found, suggesting that the mechanism of action of the extracts in their antioxidant activity may be identical, being related to the content in total phenols.

In Table 3 we present the $\mathrm{EC}_{50}$ values for reducing power, DPPH scavenging effects and inhibition of hemolysis obtained from leaves methanolic extracts.

In conclusion, methanolic extracts from leaves without copper treatment revealed better antioxidant properties than leaves treated with different copper formulations (lower $\mathrm{EC}_{50}$ values), which is in agreement with the higher content of phenols found in the control. The $\mathrm{EC}_{50}$ values obtained for reducing power and scavenging effects on DPPH radicals were higher than for hemolysis inhibition mediated by peroxyl free radicals. The use of $\mathrm{Cu}(\mathrm{OCl})_{2}$ is not recommended when olive leaves are to be used in phytotherapy, due to its high persistence and reduced power, scavenging effect on DPPH and hemolysis inhibition.

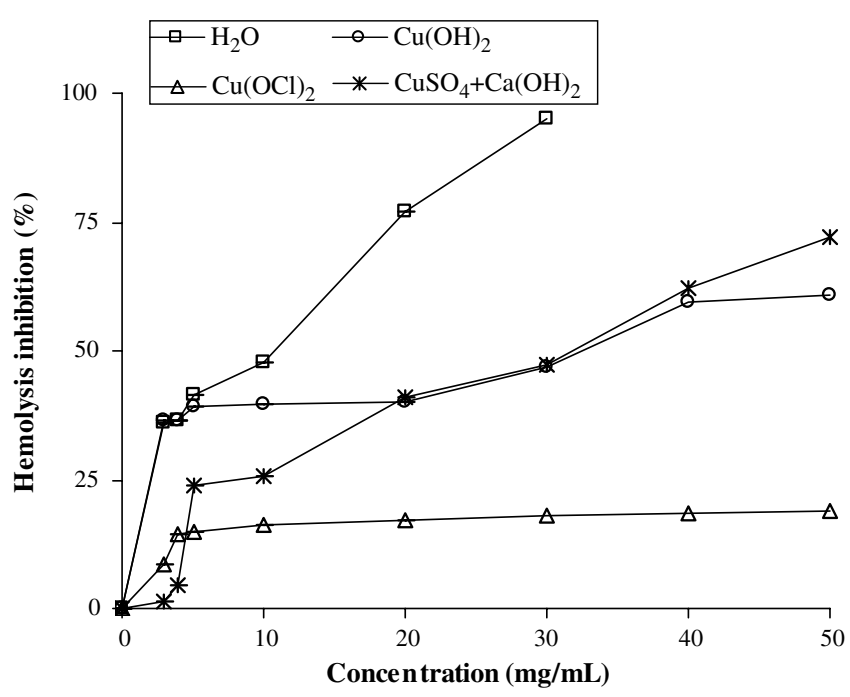

Fig. 5. Hemolysis inhibition (\%) of methanolic extracts from Olea europaea L. ( $C v$. Cobrançosa) leaves. Each value is expressed as mean \pm standard deviation $(n=3)$. 
Table 3

$\mathrm{EC}_{50}$ values $^{\mathrm{a}, \mathrm{b}, \mathrm{c}}(\mathrm{mg} / \mathrm{ml})$ of Olea europaea $\mathrm{L}$. (Cv. Cobrançosa) leaves extracts in reducing power, DPPH scavenging and hemolysis inhibition assays

\begin{tabular}{lllc}
\hline Samples & $\begin{array}{l}\text { Reducing power } \\
\left(\mathrm{EC}_{50}{ }^{\mathrm{a}}\right)\end{array}$ & $\begin{array}{l}\mathrm{DPPH} \\
\left(\mathrm{EC}_{50}{ }^{\mathrm{b}}\right)\end{array}$ & $\begin{array}{l}\text { Hemolysis } \\
\left(\mathrm{EC}_{50}{ }^{\mathrm{c}}\right)\end{array}$ \\
\hline $\mathrm{H}_{2} \mathrm{O}$ & 1.17 & 0.91 & 10.7 \\
$\mathrm{Cu}(\mathrm{OH})_{2}$ & 1.62 & 1.52 & 32.4 \\
$\mathrm{Cu}(\mathrm{OCl})_{2}$ & 2.91 & 2.32 & $>50$ \\
$\mathrm{CuSO}_{4}+\mathrm{Cu}(\mathrm{OH})_{2}$ & 1.49 & 1.26 & 31.8 \\
\hline
\end{tabular}

${ }^{\mathrm{a}} \mathrm{EC}_{50}(\mathrm{mg} / \mathrm{ml})$ : effective concentration at which the absorbance is 0.5 .

${ }^{\mathrm{b}} \mathrm{EC}_{50}(\mathrm{mg} / \mathrm{ml})$ : effective concentration at which $50 \%$ of DPPH radicals are scavenged.

${ }^{\mathrm{c}} \mathrm{EC}_{50}(\mathrm{mg} / \mathrm{ml})$ : effective concentration at which $50 \%$ of peroxyl radicals are scavenged (erythrocyte hemolysis is mediated by peroxyl free radicals).

\section{References}

Aust, S. D., \& Sringen, B. A. (1982). Free radicals in biology (Vol. 5). New York: Academic Press, pp. 1-28.

Benavente-García, O., Castillo, J., Lorente, J., Ortuño, A., \& Del Rio, J. A. (2000). Antioxidant activity of phenolics from Olea europaea L. leaves. Food Chemistry, 68, 457-462.

Bors, W., \& Saran, M. (1987). Radical scavenging by flavonoid antioxidants. Free Radical Research Communications, 2, 289-294.

Bouaziz, M., \& Sayadi, S. (2005). Isolation and evaluation of antioxidants from leaves of a Tunisian cultivar olive tree. European Journal of Lipid Science and Technology, 107, 497-504.

Briante, R., Cara, F. L., Febbraio, F., Patumi, M., \& Nucci, R. (2002). Bioactive derivatives from oleuropein by a biotransformation on Olea europaea leaf extracts. Journal of Biotechnology, 93, 109-119.

Briante, R., Patumi, M., Terenziani, S., Bismuto, E., Febbraio, F., \& Nucci, R. (2002). Olea europaea L. leaf extract and derivatives: antioxidant properties. Journal of Agricultural and Food Chemistry, 50, 4934-4940.

Bruneton, \& Iridoides, J. (1993). In: Pharmacogosie, phytochimie, plantes médicinales (pp. 475-492). Paris, France: EC \& DOC.

De Leonardis, A., \& Macciola, V. (2002). Catalytic effect of the $\mathrm{Cu}(\mathrm{II})-$ and $\mathrm{Fe}(\mathrm{III})$-cyclo-hexanebutyrates on olive oil oxidation measured by Rancimat. European Journal of Lipid Science and Technology, 104, $156-160$.

Ferreira, I. C. F. R., Queiroz, M.-J. R. P., Vilas-Boas, M., Estevinho, L. M., Begouin, A., \& Kirsch, G. (2006). Evaluation of the antioxidant properties of diarylamines in the benzo[b]thiophene series by free radical scavenging activity and reducing power. Bioorganic and Medicinal Chemistry Letters, 16, 1384-1387.

Ferreres, F., Sousa, C., Vrchovska, V., Valentão, P., Pereira, J. A., Seabra, R. M., et al. (2006). Chemical composition and antioxidant activity of tronchuda cabbage internal leaves. European Food Research and Technology, 222, 88-98.

Fukushima, N. S., \& Tsuda, H. (1985). Carcinogenity and modification of the carcinogenic response by BHA, BHT and other antioxidants. Critical Reviews in Toxicology, 15, 109-150.

Garcia, O. B., Castillo, J., Lorente, J., Ortuno, A., \& Del-Rio, J. A. (2000). Antioxidant activity of phenolics extracted from Olea europaea $\mathrm{L}$. leaves. Food Chemistry, 68, 457-462.

Gomes, H.B., \& Cavaco, M. (2003). Protecção Integrada da Oliveira-Lista dos produtos fitofarmacêuticos, níveis económicos de ataque (pp 55). Ministério da Agricultura, Desenvolvimento Rural e Pescas- Direcção Geral de Protecção das Culturas: Oeiras.

Gordon, M. H., Paiva-Martins, F., \& Almeida, M. (2001). Antioxidant activity of hydroxytyrosol acetate compared with that of other olive oil polyphenols. Journal of Agricultural and Food Chemistry, 49, 2480-2485.

Guinda, A., Albi, T., Camino, M. C. P., \& Lanzón, A. (2004). Supplementation of oils with oleanolic acid from the olive leaf (Olea europaea). European Journal of Lipid Science and Technology, 106, $22-26$.

Halliwell, B. (1997). Antioxidants in human health and disease. Annual Review of Nutrition, 16, 33-50.

Halliwell, B., \& Gutteridge, J. M. C. (1999). Free radicals in biology and medicine. United Kingdom: Oxford University Press.

Hatano, T., Kagawa, H., Yasuhara, T., \& Okuda, T. (1988). Two new flavonoids and other constituents in licorice root: their relative astringency and radical scavenging effects. Chemical and Pharmaceutical Bulletin, 36, 2090-2097.

Hellemont, J. V. (1986). Compendium de phythotherapie. Bruxelles, pp. 268-270.

Keys, A. (1995). Mediterranean diet and public health personal reflection. American Journal of Clinical Nutrition, 61, 1321S-1323S.

La Pera, L., Lo Coco, F., Mavrogeni, E., Giuffrida, D., \& Dugo, G. (2002). Determination of copper (II), lead (II), cadmium (II) and zinc (II) in virgin olive oils produced in Sicily and Apulia by derivative potentiometric stripping analysis. Italian Journal of Food Science, 14, 389-399.

Lipworth, L., Martinez, M. E., Angell, J., Hsien, C. C., \& Trichopoulos, D. (1997). Olive oil and human cancer: an assessment of evidence. Preventative Medicine, 26, 181-190

Meirinhos, J., Silva, B. M., Valentão, P., Seabra, R. M., Pereira, J. A., Dias, A., et al. (2005). Analysis and quantification of flavonoidic compounds from Portuguese olive (Olea europaea L.) leaf cultivars. Natural Product Research, 19, 189-195.

Miki, M., Tamia, H., Mino, M., Yamamoto, Y., \& Niki, E. (1987). Freeradical chain oxidation of rat read blood cells by molecular oxygen and its inhibition by $\alpha$-tocopherol. Archives of Biochemistry and Biophysics, 258, 373-380.

Monteiro, A. M. (1999). A oliveira. série património natural transmontano (pp. 155). João Azevedo Editor: Mirandela.

Oyaizu, M. (1986). Studies on products of browning reactions: Antioxidative activities of products of browning reaction prepared from glucosamine. Japanese Journal of Nutrition, 44, 307-315.

Paiva-Martins, F., \& Gordon, M. H. (2001). Isolation and characterization of the antioxidant component 3,4-dihydroxyphenylethyl 4-formyl-3-formylmethyl-4-hexenoate from olive (Olea europaea) leaves. Journal of Agricultural and Food Chemistry, 49, 4214-4219.

Paiva-Martins, F., Gordon, M. H., \& Gameiro, P. (2003). Activity and location of olive oil phenolic antioxidants in liposomes. Chemistry and Physics of Lipids, 124, 23-36.

PDR for Herbal Medicines (1998) (pp. 999-1000). New Jersey: Medical Economics Company.

Pryor, W. A., Lightsey, J. W., \& Prier, D. G. (1982)The production of free radicals in vivo from the action of xenobiotics: the initiation of autooxidation of polyunsaturated fatty acids by nitrogen dioxide and ozone. In lipid peroxides in biology and medicine. New York: Academic Press, pp. 1-22.

Ranalli, A., Contento, S., Lucera, L., Febo, M. D., Marchegiani, D., \& Fonzo, V. D. (2006). Factors affecting the contents of Iridoid Oleuropein in olive leaves (Olea europaea L.). Journal of Agricultual and Food Chemistry, 54, 434-440.

Samuelsson, G. (1951). The blood pressure lowering factor in leaves of Olea europaea. Farmacevtisk Revy, 15, 229-239.

Savournin, C., Baghdikian, B., Elias, R., Dargouth-Kesraoui, F., Boukef, K., \& Balansard, G. (2001). Rapid high-performance liquid chromatography analysis for the quantitative determination of Oleuropein in Olea europaea leaves. Journal of Agricultural and Food Chemistry, 49, 618-621.

Singleton, V. L., \& Rossi, J. A. Jr., (1965). Colorimetric of total phenolics with phosphomolybdic-phosphotungstic acid reagents. American Journal of Enology and Viticulture, 16, 144-158.

Skerget, M., Kotnik, P., Hadolin, M., Hras, A. R., Simonic, M., \& Knez, Z. (2005). Phenols, proanthocyanidins, flavones and flavonols in some plant materials and their antioxidant activities. Food Chemistry, 89, 191-198. 
Soveral-Dias, J. C., Jordão, P. V., Marcelo, M. E., Calouro, F., Antunes, A. F., Cordeiro, A. M., Santos, L. S., \& Morais, N. C. (2000). Produção Integrada da oliveira. Fertilização e outras Práticas Culturais. MADRP, INIA, DGPC, DGDR: Lisboa.

Stone, W. L., Leclair, I., Ponder, T., Bagss, G., \& Barret-Reis, B. (2003). Infants discriminate between natural and synthetic vitamin E. American Journal of Clinical Nutrition, 77, 899-906.

Tabera, J., Guinda, A., Ruiz-Rodriguez, A., Senorans, J. F., Ibanez, E., Albi, T., et al. (2004). Countercurrent supercritical fluid extraction and fractionation of high-added-value compounds from a hexane extract of olive leaves. Journal of Agricultural and Food Chemistry, 52, 4774-4779.
Torel, J., Cillard, J., \& Cillard, P. (1986). Antioxidant activity of flavonoids and reactivity with peroxy radical. Phytochemistry, 2, 383-385.

Trapero, A., \& Blanco, M. A. (1999). Enfermedades. In D. Barranco, R. Fernández-Escobar, \& L. Rallo (Eds.), El Cultivo del Olivo (pp. 479-532). Junta de Andalucía: Junta de Andalucía-MundiPrensa.

Visioli, F., Bellomo, G., \& Galli, C. (1998). Free-radical-scavenging properties of olive oil polyphenols. Biochemical and Biophysical. Research Communications, 247, 60-64.

Visioli, F., Bellosta, S., \& Galli, C. (1998). Oleuropein, the bitter principle of olives enhances nitric oxide production by mouse macrophages. Life Sciences, 62, 541-546.

Zarzuelo, A. (1991). Vasodilator effect of olive leaf. Planta Medica, 57, 417-419. 